\title{
新しい超過洪水波形の作成方法の提案 及び基本高水ピーク流量の問題点の検討
}

\author{
江蔵 拓 ${ }^{1} \cdot$ 小川 厚次 ${ }^{2 *} \cdot$ 手計 太-3 \\ 1富山県土木部（†930-8501 富山県富山市総曲輪1番7号） \\ 2富山県立大学大学院工学研究科環境工学専攻（广939-0398 富山県射水市黒河5180) \\ 3 富山県立大学工学部環境工学科講師（干939-0398 富山県射水市黒河5180） \\ * E-mail: s09068123170@gmail.com
}

\begin{abstract}
近年，水災害のリスクが高まっており，これまでに多くの洪水防止・緩和対策が実施されてきた。しか し，万全の対策には未だ至っておらず，適切な流域計画のあり方が見直されてきている. 河川計画の基盤 となる基本高水流量は，一般的に過去の雨量データ及び実際に発生した洪水データを基に設定されている. しかしながら, 雨量データは観測流量データに比べ豊富であるものの, 降雨流出モデルの使用や降雨時間 スケールの引き伸ばしにあたり不確実性がみられるという短所がある. 本研究では, 実際の既往洪水の観 測流量データの波形を利用して，超過洪水モデルを作成する方法を提案した．本モデルを富山県の社会， 経済の基盤をなしている神通川流域に適用した結果，神通川流域における越水の危険性の高い地点を明ら かにした. また, 神通川の基本高水流量について考察した結果, 既存の基本高水流量 $9700 \mathrm{~m}^{3} / \mathrm{s}$ は $1 / 150$ 年 規模であるが，GEV分布を用いると $1 / 500$ 年規模であることが分かった．加えて，検証に用いられている 確率分布関数10個を比較すると大きなバラつきが認められた.
\end{abstract}

Key Words : watershed management, flood exceeding the designed level models, the Jinzu River, design flood discharge, overflow

\section{1. はじめに}

近年，日本国内における異常気象に伴う洪水等の水災 害が増加してきている．特に，都市部における発生は著 しく，既往対策は充分に対応できておらず，現在，適切 な流域計画，河川計画のあり方が見直されてきている.

我が国では，河川水系ごとに河川整備基本方針と河川 整備計画が策定され, 利水, 治水, 環境の 3 面から最 適な流域計画が立案することが法律で定められている. 河川整備基本方針とは，長期的な視点に立った河川整備 の基本的方針や個別事業など具体的河川整備の内容を定 めず，整備の考え方を記述するものである．河川整備計 画とは，20 30 年後の河川整備の目標を明確にし，個別 事業を含む具体的な河川整備の内容を明らかにするもの である.これらの河川整備は河川計画を行う上で非常に 密接な関係にある 11 .

河川計画を進めるにあたり計画基準地点における基本 高水流量の設定が必要であり，この值は管理をする上で
有力な指標となる．基本高水流量は一般的に過去の雨量 データ及び実際に発生した洪水データを基にしている. 重要度の高い河川では 100 200 年に一度の割合で発生 する大雨による洪水を想定して基本高水流量は算出され ており，多くの河川管理地域がこの手法を採用している. 近年，治水計画を検討する中で，この基本高水流量の 決定に際して議論がなされている，従来，我が国では実 績流量のデータが少ない理由などから, 総降雨量の年超 過確率から流出解析を経て, 基本高水流量が算出されて いる。しかし，現状の手法では実績降雨の引き伸ばし率 や引き伸ばし方法, カバー率, 降雨流出モデルの選択に おいて各自治体に相違があるため, 同一法による評価と は言えず，確実な手法を追及する必要がある.

以上より，降雨データのみを計画の主軸として用いる のではなく，流量データのみによる基本高水流量の算定 も行うべきである. しかしながら現時点で流量確率手法 によって基本高水流量が算出されている実例はない. 国土交通省の直轄管理下にある一級河川では，降雨確 


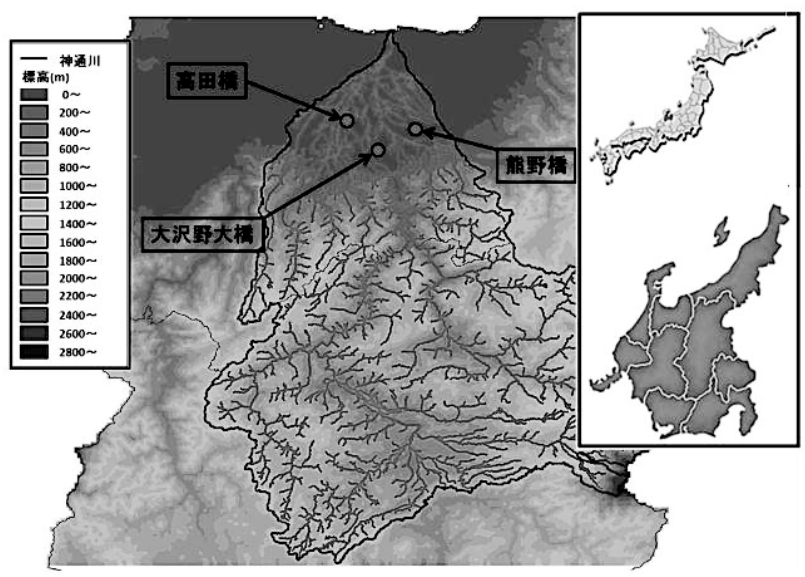

図-1 神通川流域図

率手法による值の検証に流量確率手法が用いられている。 そこで著者らのグループでは, 雨量から流量への変換 等に伴う不確実性を解消寸るため, 過去の観測流量デー タのみを利用した擬似超過洪水モデルの作成方法を提案 している2．本モデルを富山県の社会，経済の基盤をな している神通川流域に適用し，超過洪水による汇濫危険 箇所の想定を行った．また神通川流域を例に挙げ，現存 の基本高水流量の算出に関する問題点の検証を行った.

\section{2. 対象流域}

神通川は，岐阜県高山市の標高1626 mの川上岳を源と し, 富山県内の一級河川である. 流域面積は $2720 \mathrm{~km}^{2}$, 流路延長は $120 \mathrm{~km}$ ，であり，富山県第一である．河床勾 配は，源流から小鳥川合流地点までの上流部が約 $1 / 20$ 1/150, 小鳥川合流地点から神三ダム地点までの中流部 が約1/150〜1/250であり，我が国屈指の急流河川である. 神通川流域図を図-1に示寸。

下流域に位置する富山市の人口集中地区の面積は1970 年には26.4 $\mathrm{km}^{2}$ であったが，2010年には55.6 km²に拡大し ており，人口や資産，住宅地等が密集している。 また， 下流域内には北陸自動車道や国道8号, 富山空港等の富 山県全体の基盤交通ネットワークがある。このように本 流域は上記の地域の社会, 経済, 交通ネットワークの基 盤を形成しているため，汇濫の危険性が高い箇所を，正 確に把握する事は重要な課題である.

\section{3. 擬似超過洪水の作成方法}

本研究ではCategory A とCategory Bに大別して2つの擬似 超過洪水を作成した，以下に作成方法を示寸.

\section{（1）Category Aの擬似超過洪水の作成方法}

Category Aでは，既往最大洪水(2004)の観測值を基に， 擬似超過洪水を作成した。作成した擬似洪水波形は，洪
水流量増加波形(Case1), ピーク流量増加波形(Case2), 長雨波形(Case3)である. Case1-3の詳細を以下に記述し， Case1-3の条件式と大沢野大橋を対象とし得られた洪水波 形を図-2，図-3，図-4に示寸.

まず既往最大洪水時に観測された1時間当たりの流量 の増減量(以下 $\mathrm{d} \mathrm{dQ} / \mathrm{dt})$ を算出した。. 次に, 過去の観測值か ら平水時における $|\mathrm{dQ} / \mathrm{dt}|$ の変動が $40 \mathrm{~m}^{3} / \mathrm{s} / \mathrm{hr}$ 程度はあるた め, $\mathrm{dQ} / \mathrm{dt} / \mathrm{j}^{4} 40 \mathrm{~m} / \mathrm{s}$ 以下を平水区間(以下区間 $\left.\mathrm{A}\right), 40 \mathrm{~m} 3 / \mathrm{shr}$ 以上を洪水区間とした．次に，既往10個の主要洪水の洪 水時における $\mid \mathrm{dQ} / \mathrm{dt} /$ 平均值が約 $100 \mathrm{~m}^{3} / \mathrm{s} / \mathrm{hr}$, ピーク時に おける $\mathrm{dQ} / \mathrm{d} t$ 平均值が $1000 \mathrm{~m}^{3} / \mathrm{s} / \mathrm{hr}$ ，であったため，洪水 区間を次のように区別した。 $\mathrm{dQ} / \mathrm{dt} /$ が40 m/s/shr以上100 $\mathrm{m}^{3} / \mathrm{s} / \mathrm{hr}$ 以下を波形の変化が小さな洪水区間(以下区間B), $\mathrm{dQ} / \mathrm{dt} \mid$ が $100 \mathrm{~m}^{3} / \mathrm{s} / \mathrm{hr}$ 以上 $1000 \mathrm{~m}^{3} / \mathrm{s} / \mathrm{hr}$ 以下を波形の変化が大 きな洪水区間(以下区間 $\mathrm{C}$ ), $\mathrm{ddQ} / \mathrm{dt} /$ が $1000 \mathrm{~m}^{3} / \mathrm{s} / \mathrm{hr}$ 以上をピ ーク区間(以下区間D)とした.

洪水流量増加波形(Case1)の作成について記述する. Case1では既往最大洪水の総流量及びピーク流量を大き くした疑似洪水を作成した． 区間Aでは観測值を用い， 区間Bでは観測值を1 a倍(任意)，区間C-Dでは観測值をa 倍(任意)した．以上より全体の増加を図った洪水を想定 した.

ピーク流量増加波形(Case2)の作成について記述する. Case2では既往最大洪水の総流量を一定に保ち，ピーク 流量を大きくした疑似洪水を作成した． 区間Aでは観測 值を用い，区間B-Cでは観測值を $0.5 \sim 1$ 倍して減少させ， 区間Dでは観測值を 1 b 倍(任意)して増加させた．以上よ りピークに重点をおいた洪水を想定した.

長雨波形(Case3)の作成について記述する.Case3では, 既往最大洪水のピーク流量を一定に保ち, 総流量を大き くした疑似洪水を作成した。 区間Aでは観測值を用い, 区間B-C-Dではピーク流量を越さないように観測值を (1 2)c倍(任意)して増加させた. 以上より長時間, 雨が降 り続いた時の洪水を想定した.

本提案は, 各条件における区間内流量を線形的に増加 させることを前提としており, 総積分值が条件における 倍数值 (任意) となるよう設定した. また，ピーク付近で は，任意の増加係数を用いることで，波形を増加させた．

\section{（2）Category Bの擬似超過洪水の作成方法}

Category Bの洪水イベントでは，ピーク流量が第1位か ら第10位までの既往洪水波形を基に, 確率流量(150年, 300 年，400年， 500 年，1000年)を用いて擬似超過洪水を 作成した。擬似洪水波形の作成には，Case1の作成方法 と条件式を用いた．波形作成の基にした10個の既往洪水 波形を図-5に示す。確率流量算出には38年間の観測值を 使用し，一般化極值分布を用いた. 


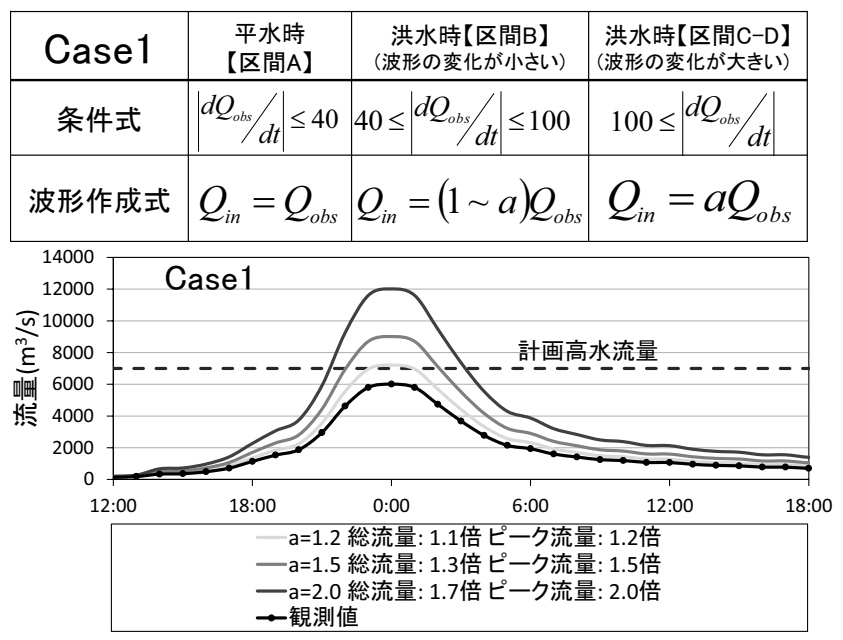

図-2 Case1 の条件式及び擬似洪水波形

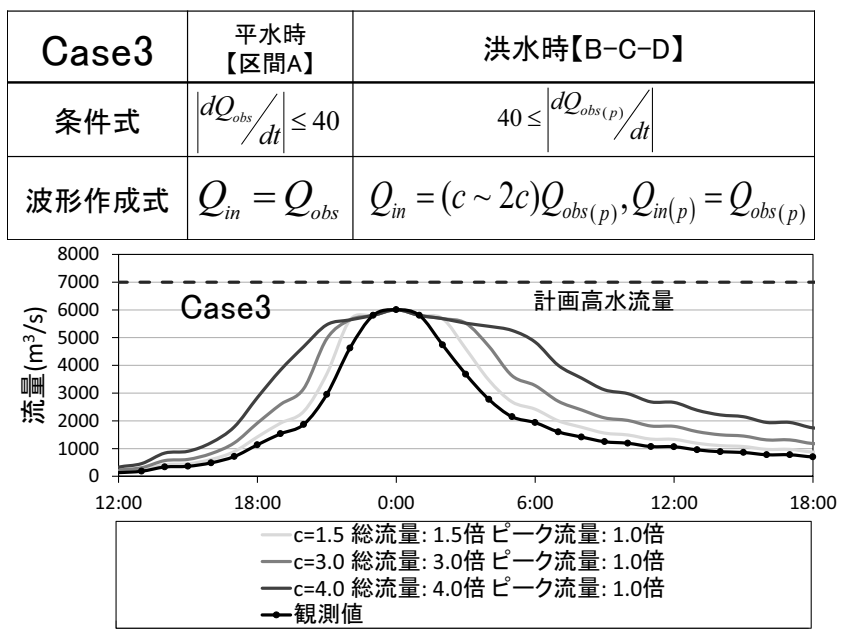

図-4 Case3 の条件式及び擬似洪水波形

\section{4. 河道計算}

本研究では1次元不定流計算による数值解析を行い, 水位計算による越水の可否に関するシミュレーションを 行った．河道計算にはサン・ブナン式を用い，基礎式は 以下に示す連続の式(1)と運動量保存式(2)である. 非定 常計算は有限差分法の陰解法で解いている.

$\frac{\partial A}{\partial t}+\frac{\partial Q}{\partial x}=0$

$\frac{\partial Q}{\partial t}+\frac{\partial}{\partial x}\left(\frac{Q^{2}}{A}\right)+g A \frac{\partial h}{\partial x}-g A I_{z}+g \frac{n^{2} Q|Q|}{A R^{4 / 3}}=0$

ここで, $h$ : 水深 $(\mathrm{m}), R$ : 径深 $(\mathrm{m}), I_{z}$ : 河床勾配, $n$ : 粗度係数 $\left(\mathrm{m}^{-1 / 3} \mathrm{~s}\right), A$ : 断面積 $\left(\mathrm{m}^{2}\right), Q$ : 流量 $\left(\mathrm{m}^{3} / \mathrm{s}\right)$, $g$ : 重力加速度 $\left(\mathrm{m} / \mathrm{s}^{2}\right)$ である.

本河道計算には，河道断面 130 箇所を利用して河道網 を作成した。流域内の上流端には流量を疑似的に与えた。 上流域に位置する河川には過去の流量データが存在しな いため，大沢野大橋地点の流量を基に，大沢野大橋より

\begin{tabular}{|c|c|c|c|}
\hline Case2 & $\begin{array}{c}\text { 平水時 } \\
\text { 【区間A】 }\end{array}$ & $\begin{array}{c}\text { 洪水時【区間B-C】 } \\
\text { (ピーク外) }\end{array}$ & $\begin{array}{c}\text { 洪水時【区間D】 } \\
\text { (ピーク) }\end{array}$ \\
\hline 条件式 & $\left|d Q_{o b s} / d t\right| \leq 40$ & $40 \leq\left|d Q_{o b s(p)} / d t\right| \leq 1000$ & $1000 \leq\left|d Q_{o b s(p)} / d t\right|$ \\
\hline 波形作成式 & $Q_{i n}=Q_{o b s}$ & $Q_{i n}=(0.5 \sim 1) Q_{o b s(p)}$ & $\begin{array}{l}Q_{i n}=(1 \sim b) Q_{o b s(p)} \\
Q_{i n(p)}=b Q_{o b s(p)}\end{array}$ \\
\hline
\end{tabular}

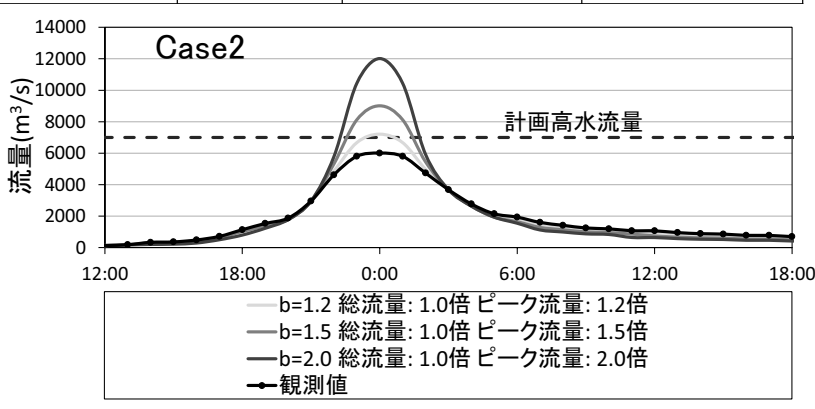

図-3 Case2 の条件式及び擬似洪水波形

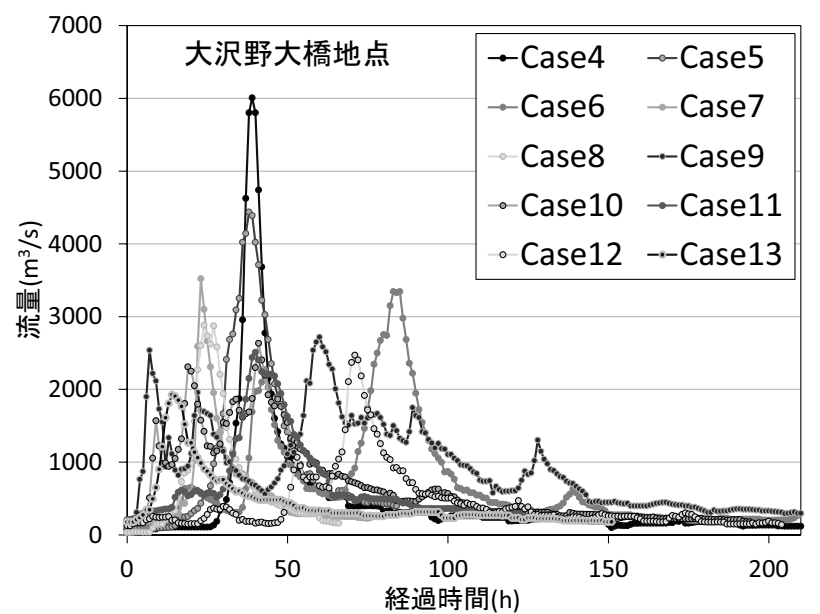

図-5 ピーク流量が第 1 から第 10 位の既往洪水波形

上流に位置する河川の断面積に応じて，与える流量の比 例配分を行った。下流端には富山湾潮位データを与えた。

下流域のみの数值実験を行う場合，流量の境界条件を 与える地点は大沢野大橋地点，熊野橋地点，井田川にお ける境界条件の高田橋地点である. 全流域の数值実験を 行う場合，流量の境界条件を与える地点は，神通川の源 である宮川，支川である川上川，小鳥川，大八賀川，小 八賀川，荒城川，高原川，蒲田川，双六川，跡津川，長 棟川，井田川の支川である別荘川，九婦須川，室牧川， 山田川，湯谷川，熊野川の支川である黒川，常顔寺川水 系のいたち川の計 22 河川の上流端である.

また，本ケースでは，計算值と実測值が最も近い值が 感度分析における整合性が最も高いと判断し，河道内の マニングの粗度係数は，低水路は $0.27 \mathrm{~m}^{-1 / 3} \mathrm{~s}$ ，洪水敷は $0.40 \mathrm{~m}^{-1 / 3} \mathrm{~s}$ とした.

数值実験を行うにあたって，下流域のみの場合は $\Delta t=0.1 \sim 5 s$, 平均 $\Delta x=24.8 \mathrm{~m}$ を用い, 全流域の場合は $\Delta t=0.1 \sim 2 s$, 平均 $\Delta x=51.9 \mathrm{~m}$ を用いた.

\section{5. 神通川流域への適用結果及び考察}




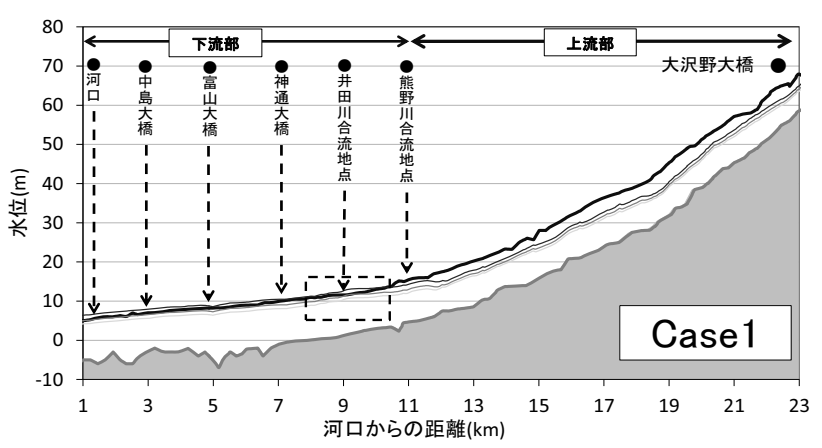

図-6 神通川下流域における水位縱断図 (Case1)

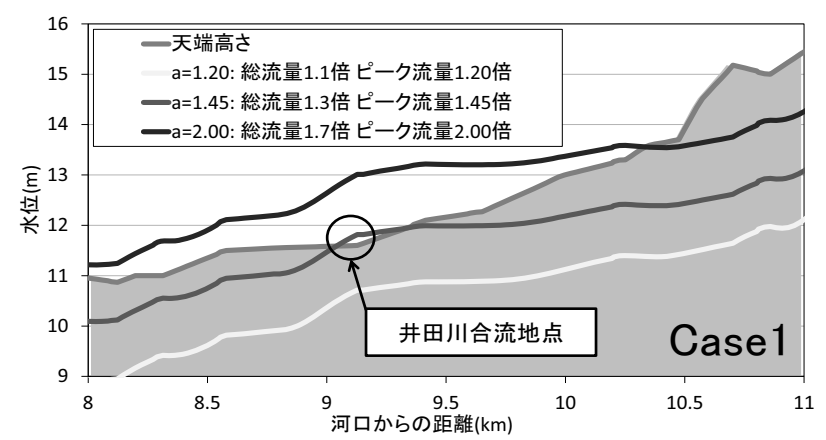

図-7 図 6 の 8-11 kmの拡大図(Case1)

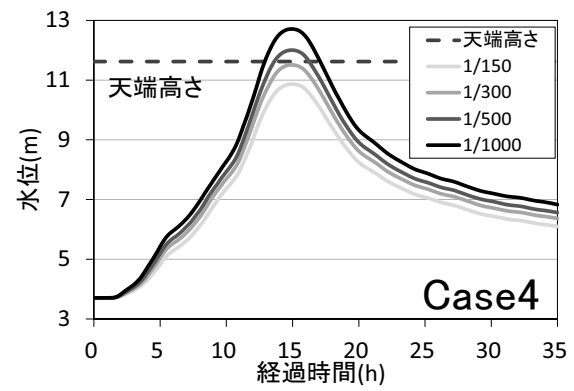

図-8 水位の経時変化 (Case4)

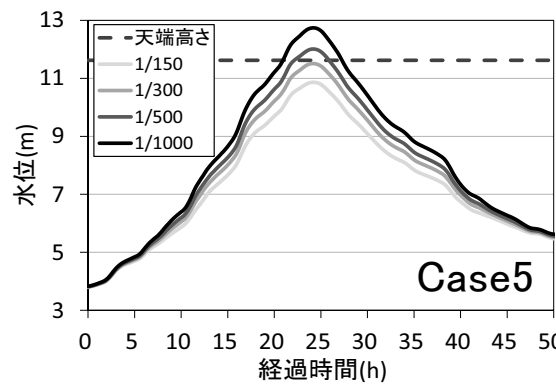

図-9 水位の経時変化 (Case5)

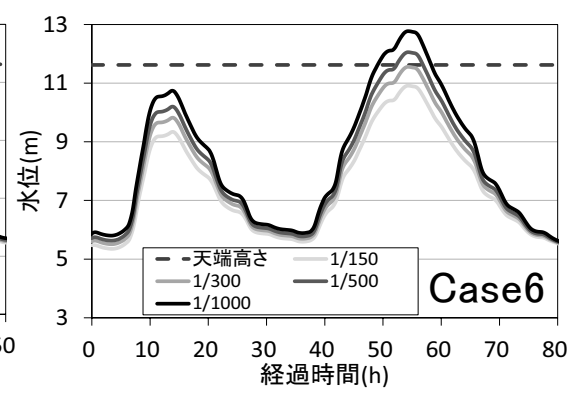

図-10 水位の経時変化 (Case6)
はじめに, Category A の結果について示寸. 洪水流量 増加波形(Case1)は 5 ケース $(\mathrm{a}=1.2,1.40,1.45,1.50,2.0)$ の数值 実験を行い，同様にピーク流量増加波形(Case2)は 5 ケー ス( $\mathrm{b}=1.2,1.45,1.48,1.5,2.0)$ ，長雨波形(Case3)は 5 ケース $(\mathrm{c}=1.2,1.5,2.0,3.0,4.0)$ の数值実験を行った. 合計 15 ケー スの数值実験を行った結果, 洪水流量増加波形(Case1)は $\mathrm{a}=1.45$, ピーク流量増加波形(Case2)は $\mathrm{b}=1.48$, 長雨波形 (Case3)は c=4.0 の時に，越水が生じた.

ここで, 例として洪水流量増加波形(Casel:a=1.2, 1.45, 2.0)の結果を図-6, 図-7 に示寸. 図-6 は大沢野大橋地点 の水位がピークに達した時の, 神通川下流域における水 位の縦断図である. $\mathrm{a}=1.45$ のとき，大沢野大橋から熊野 川合流地点の区間では, 水位から天端高さまで平均して 約 $3.37 \mathrm{~m}$ であった．熊野川合流地点から河口までの区間 では，水位から天端高さまで平均して約 $0.55 \mathrm{~m}$ であった. したがって, 熊野川合流地点から河口までの区間の方が, 水位から天端高さまでの余裕がないことがわかった.

図-7 は図-6 の $8 \mathrm{~km}$ から $11 \mathrm{~km}$ 区間の拡大図である. $\mathrm{a}=1.45$ のときに, 井田川合流地点で水位が天端高さを超 過していることが分かる.また，ピーク流量増加波形 (Case2), 長雨波形(Case3)を用いても越水が生じる箇所は, Casel と同様に井田川合流地点であった.

次に, Category Bの結果について記述する. Category B では，10 ケースの既往洪水波形を利用し，ピーク流量 には確率流量 5 ケース $(150$ 年, 300 年, 400 年, 500 年, 1000 年)用い, 合計 50 ケースの数值実験を行った.

前述した一般化極值分布用いて確率流量を算出した. その結果, 神通大橋地点において, 再現期間 50 年では
$5923 \mathrm{~m}^{3} / \mathrm{s}, 70$ 年では $6410 \mathrm{~m}^{3} / \mathrm{s}, \quad 150$ 年では $7600 \mathrm{~m}^{3} / \mathrm{s}, 300$ 年では $8798 \mathrm{~m}^{3} / \mathrm{s}, 500$ 年では $9760 \mathrm{~m}^{3} / \mathrm{s}, 1000$ 年では 11180 $\mathrm{m}^{3} / \mathrm{s}$ であった. 適合度評価 SCLC では 0.023 を示し, 精 度の良い結果が得られた。以上より，2004年 10 月 21 日 の既往最大洪水時に観測された $6412 \mathrm{~m}^{3} / \mathrm{s}$ は 70 年に一度 程度の洪水という事がわかった。

図-8，図-9，図-10 は既往最大洪水波形(Case4)，既往 第 2 位洪水波形(Case5)，既往第 3 位洪水波形(Case6)を用 いた井田川合流地点の水位の経時変化である．いずれの 洪水波形を使用しても 500 年確率洪水を用いた時に，水 位が天端高さを超過した。

また，確率流量を用いて再現期間300年規模までの洪 水に対して, Category Bの全波形(Case4-13)において越水 が生じないという結果が得られた。

本研究の数值実験により算出した既往最大洪水のピー ク時の流速值は $3.3 \mathrm{~m} / \mathrm{s}$ であった.

\section{6. 基本高水流量の課題点の検討}

国土交通省では，河川流量を用いた確率值は規定に則 って算出された基本高水流量の検証として利用されてい る. 治水安全度に見合う確率流量の上限値と下限值の間 に基本高水流量が納まれば，その基本高水流量は妥当で あると判断している. 流量確率はその統計的根拠加ら雨 量確率と同じ扱いがされているため，検証目的でなく一 義的に治水安全度に見合うピーク流量決定の基準として 採用できる可能性がある.

そこで, 本研究では, 神通川の基本高水流量を例に挙 げ，現状の基本高水流量の課題点の検討を行った，提示 
表-1 様々な確率分布モデルによる $1 / 150$ 確率流量

\begin{tabular}{|l|c|}
\hline \multicolumn{2}{|c|}{$1 / 150$ 確率流量(神通大橋地点ダム戻し流量) } \\
\hline 確率分布モデル & 確率流量 $\left(\mathrm{m}^{3} / \mathrm{s}\right)$ \\
\hline ガンベル分布 & 7400 \\
\hline 平方根指数最大值分布 & 9900 \\
\hline 一般化極值分布 & 7300 \\
\hline 対数ピアソン而型(現標本) & 7200 \\
\hline 対数ピアソン而型(積率本) & 7300 \\
\hline 岩井法 & 7700 \\
\hline 石原·高瀬法 & 7800 \\
\hline クオンタイル法 & 8300 \\
\hline 対数正規分布(3母数PMW法) & 7700 \\
\hline
\end{tabular}

表-2 確率流量算出に使用したデータの違い

\begin{tabular}{|c|c|c|}
\hline 神通大橋地点 & 国土交通省 & 本研究 \\
\hline データ期間 & 47 年間(1958-2004) & 38年間(1974-2011) \\
\hline 流量データ & ダム戻し流量 & ダム調節後の流量 \\
\hline
\end{tabular}

表-3 神通大橋地点における各確率流量

\begin{tabular}{|c|c|}
\hline 確率年 & 流量 $\left(\mathrm{m}^{3} / \mathrm{s}\right)$ \\
\hline 50 年 & 5923 \\
\hline 100 年 & 6952 \\
\hline 150 年 & 7600 \\
\hline 300 年 & 8798 \\
\hline 400 年 & 9331 \\
\hline 500 年 & 9760 \\
\hline 1000 年 & 11180 \\
\hline
\end{tabular}

\begin{tabular}{|c|c|c|r|r|r|c|}
\hline No. & 河川名 & 基準点 & \multicolumn{1}{|c|}{ 基本高水流量 $\left(\mathrm{m}^{3} / \mathrm{s}\right)$} & 推定ピーク流量 $\left(\mathrm{m}^{3} / \mathrm{s}\right)$ & 比率 & 治水安全度 \\
\hline 1 & 荒川 & 花立 & 8000 & 7300.0 & 1.10 & $1 / 100$ \\
\hline 2 & 阿賀野川 & 馬下 & 15700 & 15925.0 & 0.99 & $1 / 150$ \\
\hline 3 & 小信濃川 & 小千谷 & 13500 & 11450.0 & 0.96 & $1 / 150$ \\
\hline 4 & 姫川 & 山本 & 5000 & 3450.0 & 1.12 & $1 / 100$ \\
\hline 5 & 関川 & 高田 & 3700 & 6490.0 & 1.11 & $1 / 100$ \\
\hline 6 & 黒部川 & 愛本 & 7200 & 4312.5 & 1.11 & $1 / 100$ \\
\hline 7 & 常願寺川 & 憎岩 & 4600 & 7844.0 & 1.24 & $1 / 150$ \\
\hline 8 & 神通川 & 神通大橋 & 9700 & 5250.0 & 1.24 & $1 / 150$ \\
\hline 9 & 庄川 & 雄神 & 6500 & 1620.0 & 0.99 & $1 / 100$ \\
\hline 10 & 小矢部川 & 津沢 & 1600 & 5158.3 & 1.16 & $1 / 100$ \\
\hline 11 & 手取川 & 鶴来 & 6000 & 1445.0 & 1.18 & $1 / 100$ \\
\hline 12 & 梯川 & 小松大橋 & 1700 & & & \\
\hline
\end{tabular}

するダム戻し流量はあくまで参考值であり，雨量確率手 法を基に算出した 1/150 規模の流量(既存の基本高水流 量) と流量確率手法を基に算出した $1 / 150$ 規模の流量を対 象とした. 検証した内容を以下に示す.

\section{（1） 9種類の確率分布モデルによる基本高水流量の違い}

表-1は神通川河川整備基本計画の中で示されている確 率分布モデルを用いた神通大橋地点における1/150確率 流量である. 最少となる $1 / 150$ 確率流量は対数ピアソン III型による $7200 \mathrm{~m}^{3} / \mathrm{s}$ ，最大となる1/150確率流量は平方根 指数最大值分布による $9900 \mathrm{~m}^{3} / \mathrm{s}$ あ゙あった. 神通川におけ る基本高水流量は $9700 \mathrm{~m}^{3} / \mathrm{s}$ であり，上記の最小值から最 大值の範囲に含まれているため, この值は対象域の 1/150規模の流量として妥当であると考えられる.

その一方で，得られた $1 / 150$ 確率流量には大きなばら つきが生じた. また, 既存の基本高水流量 $9700 \mathrm{~m}^{3} / \mathrm{s}$, 得られた確率流量值の中でも高い值である. 以上より, 検証に用いる確率分布モデルの違いによって結果が異な るため，既存の計画の規模(基本高水流量)が1/150の洪水 を想定していると判断すべきではないと考えられる.

そこで本研究では，一般的に適合度が良いとされてい る一般化極值分布を用いて，既存の基本高水流量の検証 を行った. その結果を表-3に示す. 確率流量算出に使用 したデータ(表-2)は国土交通省と比較して，データ期間 が9年異なり，またダム戻し量を用いていない点が異な
るが，表-3からも既存の高水流量 $9700 \mathrm{~m}^{3} / \mathrm{s}$ は1/500規模に 相当する事が分かる，以上より，雨量確率手法を基に策 定された神通川の基本高水流量は，1/150程度と計画さ れているが，検証に用いた確率分布モデルの違いによっ ては1/150以上の計画規模である可能性がある.

\section{（2）基本高水流量と推定ピーク流量の比較}

上述した状況が神通川固有の問題であるかを検証する ため，国土交通省北陸地方整備局管内における基本高水 流量と推定ピーク流量の比較を行った. ここで用いた推 定ピーク流量とは，国土交通省が基本高水流量を決定す る際，検証に用いた確率分布モデル(SLSC0.04以下)の確 率流量の平均值のことである. その結果を表-4に示す.

北陸地方 12 地点の既存の基本高水流量と推定ピーク流 量を比較すると，9地点の基本高水流量が推定ピーク流 量を上回っている。特に，神通川は庄川とともに最も大 きい比率であり, 算出された確率年の中から, 安全側に 配慮された計画をしている結果であると推察される.

\section{7. 結論}

本研究では，疑似超過洪水モデルを構築し，様々な波 形を考慮した複数の疑似超過洪水の作成方法を提案した. 疑似超過洪水を作成するにあたって，(1)全体の増加を 図った洪水，(2)ピークに重点をおいた洪水，(3)長い時 
間雨が降り続けた時の洪水を想定した.

本研究で作成した超過洪水モデルは，過去の観測デー 夕を基に作成しており，より現実に起こり得る疑似洪水 を想定した. そのため, 計画水準の決定に際して 1 つの 指標として考え, 計画規模の妥当性の判断材料に用いる ことが出来る．また，河道計画を設けた際に，住民に対 する説明においても，明確な根拠として挙げることが容 易である.

神通川流域を対象に本モデルを適用し，汇濫危険箇所 の想定を行った. Category A では 15 ケース, Category B では 50 ケース, 合計 65 ケースの数值実験を行った。 そ の結果，神通川下流域において，最も氾濫の危険性が高 い場所は井田川合流地点であることが明らかになった。

上記の 3 地点は神通川の維持管理計画において要整備地 点として指定されているため, 計算結果の精度は良好で あったと考えられる.

また，流速についても検討を行ったところ，2004 年 10 月に発生した既往最大洪水のピーク時の神通大橋地 点における流速值を観測值から概算すると $3.1 \mathrm{~m} / \mathrm{s}$ であ った. 本研究の数值実験において算出した既往最大洪水 のピーク時の流速值は $3.3 \mathrm{~m} / \mathrm{s}$ であった. そのため, 本 研究で算出した計算結果は妥当性があると考えられる.

次に，本研究では雨量データを基に策定されている基 本高水流量と流量データを基に算出した推定ピーク流量 について考察した. その結果，既存の高水流量は，設定 した確率年より安全側に算出されていることが分かった。 これは，治水安全度が本来よりも大きく設定されていれ ば，更に安全である事を意味する。しかし，建設コスト
が高くなる上，流域全体に同程度の計画を遂行するのは 困難になるため，流域住民から合理的な納得を得るには 難しいと考えられる.

以上のような課題を克服するためにも，雨量データの みを河川計画の主軸に用いるのではなく, 流量データを 基にした河川計画も合わせて検討していく必要がある.

\section{参考文献}

1) 辻本哲郎: 気候・社会条件変化への対応を含む流域統合目標 の達成に向けた河川整備手法について, 河川技術論文集, 第 16 巻, pp.11-16, 2010.

2) 江蔵拓, 手計太一: 超過洪水モデルの作成と神通川流域への適 用, 第 40 回土木学会関東支部技術研究発表会講演概要集, II15,2013

3) 富山県庁: 新・元気とやま創造計画ウェブサイト, http:/www.pref.toyama.jp/cms_sec/1002/kj00011887-001-01.html $(2013 / 3 / 31)$

4) 藤田祐一郎, 木下晴由: 超過洪水による中小河川の河道災害, 京都大学防災研究所年報,第32 号,pp571-593, 1989.

5)㴰健太郎, 松田哲裕, 鵜飼絵美, 藤井悟, 景山健彦, 江頭進治: 中小 河川群の汇濫域における超過洪水を考慮した減災対策の評 価方法に関する研究, 河川技術論文集, 第 15 巻,pp.49-54, 2009.

6) 重枝未玲, 秋山壽一郎, 野村心平: 実測水位に基づく分布型流 出・平面 2 次元洪水追跡モデルのパラメータ最適化法, 河川 技術論文集,第 18 巻,pp.459-464, 2012.

(2013. 4. 4 受付) (2013. 8. 19 受理)

\title{
A New Flood Hydrograph Exceeding the Designed Level Model and Problems of Unregulated Peak Discharge
}

\section{Taku EZO $^{1}$, Koji OGAWA ${ }^{2}$ and Taichi TEBAKARI ${ }^{3}$}

\author{
${ }^{1}$ Department of Civil Works, Toyama Prefecture \\ ${ }^{2}$ Graduate School of Engineering, Toyama Prefectural University \\ ${ }^{3}$ Department of Environmental Engineering, Toyama Prefectural University
}

In recent years, water related disaster risks have increased all over the world, therefore both nonstructural and structural measures for flood management have been carried out. However, it is difficult to take thorough measures; therefore appropriate watershed management is being reconsidered.The unregulated peak discharge that used as important value for watershed management especially flood management is calculated using historical heavy rainfall data.Quantity of rainfall data is more plenty than river discharge data, however the hyetograph need to extend for making design flood discharge and hydrologic model has uncertainty issues. This paper proposes a new making method for flood exceeding the designed level using waveform of historical flood discharge data. The Jinzu River basin was selected for this study, which is basis of social and economic in Toyama prefecture. As a result of numerical simulation, high flood risk area was clarified in this basin.Finally, the existing design flood discharge $9700 \mathrm{~m}^{3} / \mathrm{s}$ was $1 / 150$ return period; however the value was $1 / 500$ return period estimated using the GEV distribution in this study. As the result of comparison between 10 probability distribution functions, the calculated probable discharges had large differences. 